\title{
ECONOMICS AND MORE HUMANISTIC DISCIPLINES: WHAT ARE THE SOURCES OF WISDOM FOR ANTITRUST?
}

\section{Lawrence Anthony Sulitvan $\dagger$}

The interaction between antitrust and economics is increasingly intimate. This fruitful interchange, carried on primarily in the academy but in the court room as well, offers continuing promise for antitrust. One purpose of this paper is to explore some of the limits of what antitrust can fairly hope to gain from economics. Another is to consider disciplines other than economics that antitrust scholars could pursue with profit. My thesis is that antitrust scholarship could usefully explore the styles of analysis and some of the material from the humanistic disciplines of history and philosophy, and that it might be useful to draw upon social sciences other than economics, particularly on sociology and political science. Finally, I suggest that antitrust would be well served by legal scholarship of a more conventional kind than has been displayed in recent years.

My interest is not solely in the development of antitrust rules or enforcement strategies. These activities are appropriate tasks for legal scholarship. But I have another concern-quite simply, to advance understanding of antitrust. In the university, if not in the court room, the latter endeavor is as important as is the former.

\section{The Uses of Economics in Antitrust}

A seemingly rigorous way of thinking about antitrust derives from a tradition of economic analysis that is associated primarily with the University of Chicago and Yale. This approach, here called the "Chicago school,"1 uses two static, structural models,

$\dagger$ Professor of Law, University of California School of Law (Boalt Hall).

1 The category is a loose one. I am referring to the work of scholars such as Posner, Bork, Bowman, Brozen, Demsetz, and Stigler. Significant representative works include: R. Posner, Antitrust Cases, Economic Notes and Other Materials (1974); Bork, Vertical Integration and Competitive Processes, in Public Policy Toward Mergers 139 (Weston \& Peltzmann eds. 1969), Bork, The Rule of Reason and the Per Se Concept: Price Fixing 
the competitive market and the monopolized market. From the assumptions of neoclassical economics it establishes theoretically that when an industry is monopolized, there will be less investment, lower output and higher prices than if, other things being equal, the industry were competitive. Chicago analysis asserts that where monopoly exists resource allocations will be inefficient in the sense that total consumer satisfaction, as measured by market prices, will be less than if the market were competitive.

Having only two structural models, this school relies on cartel theory as the only basis other than monopoly to explain the occurrence of non-competitive performance. Moreover, many analysts adhering to this tradition regard monopoly as rather rare and cartels as subject to great instability. The constant threat of entry and the constant discipline of inter-industry competition reduce both the probability of monopoly ${ }^{2}$ and the longevity of cartelization. ${ }^{3}$ Chicago theory recognizes few barriers to entry other than scale efficiencies and governmental action, such as tariffs, patents and franchises. ${ }^{4}$ It deals with vertical restraint through monopoly and cartel theory. Restraints that threaten foreclosure, such as tying, tend to be deemed expressions of the urge to discriminate and, though signifying some degree of horizontal power, are viewed as having no greater operational significance than other modes of discrimination. ${ }^{5}$ Resale restraints are viewed as harmful only if imposed at the instance of dealers utilizing the manufacturer to implement their own cartel. ${ }^{6}$ If such restraints are imposed by the manufacturer

and Market Dizision, 74 YALE L.J. 775 (1965) and 75 YALE L.J. 373, 375 (1966); Bowman, The Prerequisites and Effects of Resale Price Maintenance, 22 U. CHI. L. Rev. 825 (1955); Brozen, Significance of Profit Data for Antitrust Policy, in Public Policy Toward Mergers 110 (Weston \& Peltzmann, eds. 1969); Demsetz, Two Systems of Belief About Monopoly in Industrial Concentration: The New Learning 164 (Goldschmid, Mann \& Weston eds. 1974); Stigler, $A$ Theory of Oligopoly, 72 J. PoL. Econ. 44 (1964).

${ }^{2}$ See, e.g., Report of the White House Task Force on Antitrust Policy (Separate Statement of Robert H. Bork) reprinted in 2 Antrtrust L. \& Econ. Rev. 11, 53 (1968); Demsetz, supra note 1.

${ }^{3}$ See, e.g., Hay \& Kelley, An Empirical Survey of Price Fixing Conspiracies, 17 J. L. \& Econ. 13 (1974); McGee, Cartels: Organization and Functions, 27 U. CHr. L. Rev. 191 (1960).

+ Bork, supra note 2; Demsetz, supra note 1.

${ }^{5}$ See, e.g., W. Bowman, Patent and Antrtrust Law, 64-139 (1973); Bowman, Tying Arrangements and the Leverage Problem, 67 Y $\mathrm{ALE}$ L.J. 19 (1957); Stigler, United States v. Loew's Inc.: A Note on Block Booking, 1963 S. CT. Rev. 152.

${ }^{6}$ Bowman, supra note 1; Bork, The Rule of Reason and the Per Se Concept: Price Fixing and Market Division, 75 YALE L.J. 373, 405-1 0 (1966). 
they are regarded as incapable of raising prices above a competitive level because of competition from substitute products and adjacent industries, and the threat of new entry. ${ }^{7}$ Since the manufacturer is assumed, theoretically, to be acting in its own self interest and subject to the discipline of the market, it is inferred that these restraints are efficiency producing. A manufacturer's minimum resale price, for example, may be aimed at achieving the most efficient relationship between manufacturer and dealer promotion. ${ }^{8}$ So viewed, it is a contrivance intended to induce dealers who, in their own competitive striving, will seek to expand sales so long as their costs are below the minimum price, to keep spending more for promotion until their marginal costs and marginal revenues intersect.

Chicago theory makes for an attractively tidy antitrust world. Because private markets work surpassingly well so long as government does not interfere with them, and because most apparent aberrations turn out upon analysis to reflect efficiency producing decisions by traders operating under the constraints of competitive pressure, the antitrust policemen need not be exceedingly busy. It is necessary to keep a sharp eye out for cartels, of course, for, though cartels are always under pressure and soon fall apart, they may do some harm before that inevitable end. ${ }^{9}$ Thus, there is some socially efficient level of investment in antitrust enforcement. All that remains is for Congress to work out an efficient matrix of deterrents, and for enforcement agencies to direct their activities solely toward those violations that Chicago school theory identifies as socially harmful. ${ }^{10}$

An alternative way to draw upon neoclassical economics in dealing with antitrust is exemplified by a style of inquiry proposing more complex and realistic models even at the cost of less precise theoretical solutions. This tradition, ${ }^{11}$ here called the

\footnotetext{
${ }^{7}$ Bork, supra note 6, at 411-24.

${ }^{8}$ R. Posner, Antitrust Cases, Economic Notes and Other Materials 554-55 (1974).

${ }^{9}$ E.g., Posner, Oligopoly and the Antitrust Laws: A Suggested Approach, 21 Sran. L. Rev. 1562 (1969).

${ }^{10}$ See Posner, A Program for the Antitrust Division, 38 U. CHI. L. Rev. 500 (1971).

11 This category, although I call it a school, is even looser than the Chicago-Yale school. I refer here to the work of a wider range of scholars, including Mason, Bain, Scherer, Kaysen, Turner, Bok, Comanor and Williamson. Significant representative works include: J. Bain, Barriers to New Competition (1956); C. Kaysen \& D. TuRner, Antitrust Policy (1959); F. Scherer, Industrial Market Structure and Economic Performance (1970); Bok, Section 7 of the Clayton Act and the Merging of Law and Economics,
} 
"Harvard school,"12 is less cohesive, more open, than the Chicago school. Harvard analysis is less likely than is the Chicago analysis to attribute oligopolistic industry structure to scale efficiencies. Harvard theorists recognize other barriers to entry, such as control of scarce resources, high capital requirements, and product differentiation. ${ }^{13}$ Harvard theorists follow the Chicago school in adopting the monopoly and competition models, and likewise regard cartelization as being a greater risk in markets of few sellers than in markets of many, but Harvard theory envisages the additional possibility of non-collusive but interdependent pricing in oligopolistic markets. ${ }^{14}$ Also, Harvard theorists sometimes use dynamic models suggesting ways in which foreclosing restraints like tying, requirements contracts, or vertical mergers may injure competition. Thus they perceive the possibility that vertical relationships may inhibit entry. They also regard certain characteristic aspects of competitive style, such as high advertising expenditures, as capable of dampening competition either by increasing capital requirements for entry, or by increasing product differentiation and, thereby, tending to disaggregate markets. ${ }^{15}$ The Harvard school is more likely than Chicago to view resale restrictions as pernicious. ${ }^{16}$ Harvard theory, like Chicago theory, condemns resale restrictions implemented by dealer cartels, ${ }^{17}$ but even when the impetus for

74 HARv. L. REv. 226 (1960); Comanor, Vertical Territorial and Customer Restrictions: White Motor and Its Aftermath, 81 HaRv. L. Rev. 1419 (1968); Mason, Monopoly in Law and Economics, 47 Yale L.J. 34 (1937); Turner, Antitrust Policy and the Cellophane Case, 70 Harv. L. Rev. 281 (1956); Williamson, The Economics of Antitrust: Transaction Cost Considerations, 122 U. PA. L. Rev. 1439 (1974).

${ }^{12}$ It is much harder to defend this label than it is the Chicago school label since I include within the Harvard school a diffuse group of scholars from various institutions. The label is, however, a convenient one and I use it because Mason, who is in some sense the intellectual progenitor of the kind of industrial organization economics to which I refer, did his work at Harvard, and because he, Bain, Kaysen, Turner, Bok and others worked as a group at Harvard in the mid to late 1950's. See Mason, Introduction to C. Kaysen \& D. TURNer, ANTITrust Policy (1959).

${ }^{13}$ See J. Bain, Barriers to New Competition (1956).

${ }^{14}$ See F. Scherer, Industrial Market Structure and Economic Performance $131-57$ (1970). 1974).

${ }^{15}$ E.g., P. Areeda, Antitrust Analysis, Problems, Text and Cases 18-19 (2d ed.

${ }^{16}$ E.g., Comanor, Vertical Territorial and Customer Restrictions: White Motor and its Aftermath, 81 HaRv. L. Rev. 1419 (1968); see generally Schildkraudt, Areas of Primary Responsibility and Other Territorial Restraints in Channels of Distribution Under the Antitrust Laws: A Legal and Economic Analysis, 11 Colum. J. L. \& Soc. Prob. 509 (1975).

${ }^{17}$ Compare authorities cited supra note 6 and accompanying text with, e.g., Comanor, supra note 16. 
such restraints comes from the manufacturer, Harvard analysts see them as potentially harmful. ${ }^{18}$

Neoclassical economics is, perhaps, the most rigorous and narrowly focused of the social sciences. Regardless of how complex its models may become, they are mechanical models drawn by analogy from a Newtonian view of the physical universe. Its categories are precisely defined and discrete. Reliance upon such a mode of analysis in antitrust may lead to an unduly limited conception of statutory purpose. This risk is particularly acute with Chicago theory. Indeed Chicago analysts tend to identify the efficient allocation of resources, a value derived from neoclassical economics, as the sole goal of antitrust. ${ }^{19}$ Professor Bork, who is associated with this school, has argued that the legislative history of the Sherman Act warrants the conclusion that allocative efficiency was the sole concern of Congress. ${ }^{20} \mathrm{De}-$ spite the brilliance of Bork's argument, it is not likely to convince one who does not start with the view that allocative efficiency is the only concern with which the Act ought to deal. Both Thorelli's far richer study of the Act and its antecedents ${ }^{21}$ and Letwin's historical excursion ${ }^{22}$ carry conviction that congressional purpose was both vaguer and broader than Chicago analysts will allow. ${ }^{23}$ Moreover, the vagueness and generality of the Sherman Act suggest the legitimacy and normative force of the interpretation of the Act that has found expression in its judicial development. If there is anything that was settled by the debate about statutory purpose between Professors Bork and Bowman, on the one side, and Professors Blake and Jones, on the other, it is that for nearly a century the courts have taken a vastly wider view of the objectives of antitrust than those suggested by economics. ${ }^{24}$

When one sets antitrust in a broader historical context, and

${ }^{18}$ Comanor, supra note 16.

${ }^{19}$ See, e.g., R. POSNER, supra note 1, at 5-14 (1974).

${ }^{20}$ Bork, Legislative Intent and the Policy of the Sherman Act, 9 J. L. \& Econ. 7 (1966).

${ }^{21} \mathrm{H}$. Thorelli, The Federal antitrust Policy (1955). See Blake \& Jones, Toward A Three-Dimensional Antitrust Policy, 65 Colum. L. Rev. 422, 422-23 (1965).

22 W. Letwin, Law and EConomic Policy in America (1965).

${ }^{23}$ The legislative history of subsidiary antitrust statutes is even more convincing that the concern of Congress embraced goals such as individual freedom, entrepreneurial opportunity, independence, local control of industry, and the political objective of self policing markets. See, e.g., Brown Shoe Co. v. United States, 370 U.S. 294, 311-23 (1962) (discussing legislative history of $\$ 7$ of Clayton Act as amended).

${ }^{24}$ Compare Bork \& Bowman, The Crisis in Antitrust, 65 Colum. L. Rev. 363 (1965) with Blake \& Jones, supra note 21. 
tries to assign it its proper place in the evolution of social ideas in America, the conclusion that antitrust has a wider office than Bork suggests becomes well nigh irresistible. The technological and economic changes occurring after the Civil War transformed American industry in ways that affected virtually every aspect of American life. The nation was integrated with a system of railroads and a telephone and telegraph network. New methods of mineral extraction, new sources of energy, new methods of steel production, and new techniques for preserving and shipping food all had their impacts. The scale of industrial activity expanded rapidly and dramatically and as it did so, the scale and scope of political and community life expanded in reaction. All of this yielded the tensions and ambivalences that are inevitably associated with profound changes in the conditions of life. The Sherman Act took form in that atmosphere. It was, indeed, one of the few significant American governmental responses to the transformation of American life resulting from economic development during the last decades of the nineteenth century. No one who knows anything about life or politics could expect to find theoretical rigor or doctrinal purity in such a statutory instrument.

Hofstadter is persuasive that antitrust expresses an abiding American conservatism, a perennial American impulse to find ways to divide, limit and diffuse both governmental and nongovernmental power. ${ }^{25}$ It is not that this impulse has ever stood unchallenged on the scene. It has not. There has been an ongoing dialectic between those who would contain great power and those who would invite its use, either by the private sector or by government. The Sherman Act is seen most fully as one product of that dialectic. The Act was invoked by the same kinds of social and political pressures as those to which Populism and the Progressive Movement responded, each in its unique way. ${ }^{26}$ In the history of American political and social ideas, the Sherman Act was in an important sense more clearly prefigured by Jacksonian attacks on the "monopolistic" Bank of the United States, ${ }^{27}$ than it

${ }^{25} \mathrm{R}$. Hofstadter, What Happened to the Antritrust Movement? in The Paranold Style in American Politics and Other Essays 233 (1965).

${ }^{26}$ See R. Hofstadtêr, THe Age of Reform (1955).

${ }^{27}$ See, e.g., M. Meyers, The Jacksonian Persuasion: Politics and Belief (1960), which stresses the role of ideology in the attacks on the bank and exemplifies a way of approaching problems of relative values and policy that may have uses for the law. For an earlier exploration of relationships between concepts of public interest and regula- 
was by anything early economists had to say about efficiency. ${ }^{28}$

The static models of economics fail to illuminate antitrust's role as a response to, and later as a mediator of the profound changes in technology and industrial structure that have occurred in America over the course of the present century. If the currently conventional techniques of neoclassical economics had been brought to bear each year to prepare a national report on these changes, what would these reports have said? Most would have taken note of increases in efficiency in producing and distributing goods. Many would have questioned whether large firms, or groups of firms, were gaining market power that might increase consumer prices. Several might have attempted to compare consumer losses due to market power with efficiency gains. Several might have had something to say about increases in the variety of goods and in consumer conveniences. Some might have noted salient distributional effects of some of the technological changes that were occurring. In short, they would have focused on the phenomena of market structure to which economic analysis is attuned. Yet one suspects that no such study based on conventional modes of economic analysis would take account of the non-material and less readily quantifiable welfare consequences of change in technology and industrial structure. Americans today live out their lives in a vastly different world than that of their fathers and grandfathers. The social, political and economic institutions through which they express themselves are almost all on a larger scale now than they were at the end of the last century. Many of the forces that now affect them are less personal, more remote, than they used to be. A people may care about these changes as well as about changes in efficiency and market power. They may expect policy about industrial structure to deal with their concerns, and it would be incongruous to suppose that antitrust would not reflect such solicitude.

Fortunately, antitrust courts have not limited their inquiries to the categories identified by economists. Theoretical economics

\footnotetext{
tion of economic activity, see O. Handlin \& M. Handlin, Commonwealth: A Study of the Role of Governmest in the AMerican Economy: MassachusetTs, 1744-1861 (rev. ed. 1969).

${ }^{28}$ Even as late as the turn of the century leading economists found little reason for concern in increasing industrial concentration. See, e.g., Clark, The Society of the Future, 53 The INDEPENDENT 1649 (1901) reprinted in Democracy and the Gospel of Wealth 77 (G. Kennedy, ed. 1949) [hereinafter cited as Gospel of Wealth].
} 
has informed and at times infused the development of antitrust in the years since $1890 .^{29}$ But a comprehensive search for the meaning and significance of antitrust, as it has changed over the years, must supplement the study of case law with something more than economics. The changing perceptions of and attitudes about antitrust that ultimately affect its content-and I am speaking very broadly here of the views and attitudes of the bench, the bar, the legislative and executive branches, and the constituencies of business, labor, and consumers affected by the law-are interrelated with changes in social and political attitudes that have affected other American institutions as well. ${ }^{30}$ One seeking to identify the social forces mediated and the values expressed through antitrust during the early years of this century will learn more from the "gospel of wealth" literature and its contemporary critics, than from economists of the period. ${ }^{31}$ One seeking to learn what antitrust was concerned with in the 1930's can learn more from the "business commonwealth" exponents, and their contemporary critics, than from what economists had to say during that decade. ${ }^{32}$ Here, again, the unify-

\footnotetext{
${ }^{29}$ See, e.g., United States v. Aluminum Co. of America, 148 F.2d 416 (2d Cir. 1945).

${ }^{30}$ Once again, one may turn with profit to the historical literature. See, e.g., E.
} Hawley, The New Deal and the Problem of Monopoly: A Study in Economic AMBivalence (1966) (examining the vagueness and ambivalence of New Deal policy as national economics planners, competitive marketeers, and proponents of cartelization vied with each other in an effort to reconcile 19th century ideals with 20th century industrial structure); M. Keller, The Life Insurance ENTERPRISE, 1885-1910: A STUdy of THE Limits of Corporate Power (1963) (sketching an interesting picture of socially dominant attitudes toward laissez-faire during the late 19th century); A. PAUL, Conservative Crusis and the Rule of Law: Attitudes of Bar and Bench, 1887-1895 (1960) (analyzing attitudes affecting late 19th century shifts in judicial policy affecting conomic matters); R. WIERE, ThE SEARCH FOR ORDER, 1877-1920 (1967) (analyzing shifts in values associated with the emergence of a mass society).

${ }^{31}$ The extensive literature that associated material progress with moral worth and the literature of a social Darwinism that saw achievement as an inexorable expression of some grand and universal design were expressive of widely held ideologies affecting social policy. See, e.g., R. Conwell, Acres of Diamonds (1890); M. Hopkins, The Law of Love and Love as Law (1868); A. Carnegie, Wealeh, 148 North Am. Rev. 653 (1889); Gospel OF WeALTh, supra note 25. But there was also current a liberal, rationalistic and pragmatic view of the effects of changes in the scale of industrial and related institutions. E.g., W. Ghent, The Next Step: A Benevolent Feudalism, 54 The INDEPENDENT 781 (1902), reprinted in GOSPEL OF WEALTH, supra note 25, at 92.

${ }^{32}$ There was during the thirties an enormous and politically effective literature that extolled cooperation among business firms and rational economic planning by assemblies of business managements, and condemned price cutting and other such competitive tactics as unethical chisling. See, e.g., W. L. Churchill, Pricing for Profit (1932); B. Javits, Business and the Public Interest (1932); C. Stevenson, The Way Out (1932). Criticism came from two directions: from exponents of collectivist, democratic, national industrial planning, which focused on social problems like poverty and power- 
ing concept is the American concern with power, a concern having political and social wellsprings, and transcending in scope the technical concept of market power articulated by economists. Judicial decisions ${ }^{33}$ and legislative developments ${ }^{34}$ have consistently reflected that concern.

It may be much the same today. One can no longer assert that antitrust is the major governmental intervention aimed at dealing with industrial transformation and its social effects. For the last fifty years or so the nation has implemented various regulatory programs, has socialized many activities and has used the taxing and spending power to affect economic conduct and performance. Nevertheless, there has never been a consensus about how much or what kinds of power can be left in private hands, or whether government is a safe or wholesome counterforce. Those issues rage as heatedly today as ever. ${ }^{35}$ Perhaps the contemporary significance of antitrust, like its past significance, lies primarily in the role it continues to play in the working out of those political and social issues. To argue, as do the Ghicago economists, that antitrust ought to be used solely to inhibit expressions of market power in a technical economic sense, is not only to miss much in the history and development of the law, but

lessness of workers, e.g., G. Soule, A Planned Society (1932); R. Tugwell \& H. Hill, OUR Economic Society AND ITs Problems (1934); and from those who wanted to reduce or limit the scale of industrial organization. See, e.g., L. BRANDEIS, THE CURSE OF Bigness (1934); F. Fretter, The Masquerade of Monopoly (1931). Hawley describes the struggle among adherents of these competing views to shape New Deal policy. E. Hawley, The New Deal and THE Problem of MoNopoly (1966).

${ }^{33}$ Simpson v. Union Oil Co., 377 U.S. 13, 19 (1964); Brown Shoe Co. v. United States, 370 U.S. 294, 344 (1962) ("It is competition, not competitors, which [the Clayton] Act protects. But we cannot fail to recognize Congress' desire to promote competition through the protection of viable, small, locally owned businesses. Congress appreciated that occasional higher costs and prices might result from the maintenance of fragmented industries and markets. It resolved these competing considerations in favor of decentralization."); Northern Pacific Railway Co. v. United States, 356 U.S. 1, 4-5 (1958); United States v. A. Schrader's Son, Inc., 252 U.S. 85, 100 (1920).

${ }^{34}$ See note 23 supra. For recent indications of the scope of congressional attitudes reflected in antitrust legislation, see the legislative history of the Hart-Scott-Rodino Antitrust Improvements Act of 1976, Pub. L. No. 94-435, 90 Stat. 1383, reported in, e.g., H.R. ReP. No. 499, 94th Cong., 2d Sess. 1, reprinted in [1976] U.S. Code Cong. \& AD. News 4054, 4054; H.R. REP. No. 1343, 94th Cong., 2d Sess. 1, reprinted in [1976] U.S. Code Cong. \& Ad. News 4054, 4078; H.R. Rep. No. 1373, 94th Cong., 2d Sess. 1, reprinted in U.S. CODE CoNG. \& Ad. News 4054, 4119; S. ReP. No. 803, 94th Cong., 2d Sess. 1.

${ }^{35}$ There is an immense literature on bureaucratic excesses and deficiencies, corporate and public. See, e.g., J. Deutsch, Selling the People's Cadillac: The Edsel and CoRporate RESPONSIBILITy (1976); W. GellHorn, Individual FreEdom and Governmental Restraints (1956); F. Hayer, The Road to Serfoom (1944); E. Lilienthal, Big Business: A New Era (1952). 
to ignore much of its potential. Champions of governmental planning to manage the industrial sector, ${ }^{36}$ as well as exponents of cartelization ${ }^{37}$ are still to be found. But today, as in the past, the other side of the field is not peopled solely by those who value efficiency and are committed to neoclassical concepts about how to achieve it. The political consensus that supports antitrust comes from other sources. Americans continue to value institutions the scale and the workings of which they can comprehend. Many continue to value the decentralization of decisionmaking power and responsibility. Many favor structures in which power in one locus may be checked by power in another. Antitrust, broadly perceived and sensitively administered, may contribute to the realization of these values. So doing, it may reduce various of the pressures for fuller governmental regulation of commercial and industrial activity. ${ }^{38}$

Issues like these are difficult ones for scholarship to deal with. They are intrinsically vague. There is no cohesive body of theory, like neoclassical micro-economics, that can be invoked surehandedly. But the difficulty does not absolve the academy if it persists in ignoring such matters. Moreover, as suggested in part II of this paper, there are traditions of inquiry and modes of analysis that might usefully be brought to bear.

Let me now turn to a very different concern about the use of economics in antitrust: the theory used may be wrong. Differences between Harvard and Chicago analysis are suggestive. ${ }^{39}$ There are points on which both cannot be right. But there are more general problems. Some have to do with the cultural validity of basic presuppositions, such as that firms are profit maximizers and individuals maximizers of utility. Firms are groups of people and people in groups are complex. ${ }^{40}$ Other problems have to do with the transposition of theory into empirical contexts. Even when a theory accurately describes how firms would act in a market meeting all of the factual assumptions of the theory, it may mislead one who reasons from the theory what

${ }^{36}$ See J. Gal.braith, The New Industrual State (1967).

${ }^{37}$ See Dewey, The Economic Theory of Antitrust: Science or Religion, 50 U. VA. L. REv. 413, 428-31 (1964); Wilson, Restrictize Practices, in Competitron, Cartels and Their Regulation 114 (J. P. Miller, ed. 1962).

${ }^{38}$ See Blake \& Jones, In Defense of Antitrust, 65 Colum. L. REv. 377 (1965).

${ }^{39}$ See text accompanying notes 41-52 infra.

${ }^{40}$ A growing literature raises questions about the reliability of neoclassical assumptions about firm conduct. See, e.g., W. Banmol, Business Behavior, Value and GRowTH (rev. ed. 1967). 
will happen in a real market if, in ways unperceived, the real does not sufficiently match the theoretical market.

Industrial organization theorists, who insist upon the existence of a functional relationship between market structure and market conduct, have tended to regard the structure of the industry rather than the conduct of the firm as the variable that antitrust policy should be used to influence. It may well be that this emphasis should be reversed. Political and practical constraints make it enormously difficult for a court or an administrative agency to alter the structure of an industry in ways that promise better industrial performance. By contrast, these institutions are well suited to the task of holding individual firms accountable for their conduct. Moreover, when industrial organization economists do examine conduct, they tend to make judgments about conduct by looking only at structure or only at structure and certain objective indicia of conduct, such as pricecost relationships. There are, however, many questions about firm conduct that might be investigated directly by examining internal correspondence, memoranda of intracorporate meetings and by interrogating corporate officers about the purposes of particular courses of conduct engaged in by the firm.

The treatment of vertical issues illustrates some of the problems mentioned above. Chicago analysts regard it as a waste of resources to attack resale restrictions imposed by manufacturers. ${ }^{41}$ Only those vertical restraints imposed at the instance of a dealers' cartel are harmful. Territorial restrictions, for example, are not seen as likely to arise from dealer cartelization. Thus a specific explanation why these arrangements are efficiency-producing becomes necessary to save theoretical presuppositions to which the analysis is anchored. Explanations sometimes used for vertical territorial restrictions are that the manufacturer imposed the restraints in order to force recalcitrant dealers to operate at efficient scale, ${ }^{42}$ or to prevent dealers from "free riding" on the services and promotions offered by others in the nonexclusive territory. ${ }^{43}$ Efficiency through scale economies is altogether a worthy goal. But any claim by a manufacturer that its program of territorial assignments is connected

\footnotetext{
${ }^{41}$ E.g., Bork, supra note 6; Posner, Antitrust Policy and the Supreme Court: An Analysis of the Restricted Distribution, Horizontal Merger and Potential Competition Decisions, 75 Colum. L. Rev. 282 (1975).

42 See R. Posner, Antrtrust Law, 160-61 (1976).

${ }^{43}$ Bork, supra note 6 , at 435 .
} 
to the achievement of scale efficiencies is likely to be specious. ${ }^{44}$ This is comprehended by the Harvard school. One spokesman applauds the trend to per se condemnation of vertical restraints, even at the instance of the manufacturer. ${ }^{45}$ Another, discussing the related question of the possible effects of vertical integration on efficiency, avoids the traditional argument that functional interdependence dictates common ownership. ${ }^{46}$ Instead, a "transactional approach" is adopted that recognizes "contractual contingencies [that may] overwhelm the limited planning capacities of parties subject to bounded rationality. . . ."47

Treatment of monopoly pricing similarly reveals the faults of a rigorous economic approach that values generalized analysis of structure above inquiry into human conduct and the disorder of the market. Harvard school analysts are more likely to utilize longer run or dynamic models, and thus to increase the realism, if also the complexity, of the analysis. Chicago analysts are likely to assume a monopolist will produce to the point where marginal cost and marginal revenue intersect and will price to clear the market. ${ }^{48}$ This yields the highest short run monopoly profit, but also does the most to attract entry. Harvard theorists are more likely to assume a limit pricing strategy, which will be calculated to yield a supra-competitive, though lower, return over a longer period. ${ }^{49}$ If one of the by-products of the Harvard penchant for complexity is fewer determinate solutions, I count that an

44 Try to picture the director of a state owned enterprise deploying distribution facilities in an effort to attain maximum efficiency. The image is so fanciful that it could be adhered to only by ignoring both the limits of practical knowledge about scale efficiency and the vitality and disorder displayed by the industrial establishment existing in reality at any given time, a disorder and disarray in the very bricks and mortar of monuments to a sequence of earlier judgments and decisions about facility size. The hypothetical director would know that he knew too little, and would be too thoroughly constricted by the status quo to permit himself to indulge in the kind of dream we have made for him. He would count himself lucky if he had the opportunity to design a single outlet in a single region approaching his best, informed judgment about appropriate plant size and service territory. How much more preposterous, then, is the picture of a manufacturer negotiating with a group of dealers, each possessed of its own real plant built to the scale that seemed appropriate to a single profit-oriented management at some earlier date, dividing markets in ways that will maximize scale efficiencies. See L. Sullivan, ANTITrust § 82 (1977).

55 Comanor, supra note 11.

46 Williamson, The Economics of Antitrust: Transaction Cost Considerations, 122 U. PA. L. REv. 1439, 1454-56 (1974).

${ }^{47}$ Id. 1450.

${ }^{48} \mathrm{R}$. POSNER, supra note 1 , at 5-14.

${ }^{49}$ See J. Bain, Industrial Organization 269-76 (2d ed. 1976); F. Scherer, INdustrial Market Structure and Economic Performance 219-31 (1970). 
advantage. It is not well to suppose that we have theoretical validation for things that are not theoretically knowable.

Wisdom is also shown by Harvard school analysts who recognize that it may be essential to move away from general theoretical models, even dynamic ones, in an effort to understand the particulars of a specific market situation. Oliver Williamson exemplifies this in a recent paper on franchise bidding. The paper criticized the contention of some Chicago theorists that franchise bidding schemes in natural monopoly industries would provide more of the benefits of free markets than is now achieved by public regulation of utilities. At the outset Williamson says:

Merely to show that regulation is flawed . . . does not establish that regulation is an inferior mode of organizing economic activity. For one thing, the disabilities of regulation are apt to vary with both the type of activity regulated and the form of regulation attempted. Secondly, before regulation is supplanted, there is an obligation to assess the properties of the proposed alternative-not only in general, but also specifically with respect to the activity in question. If the proposed mode is flawed in similar or different respects, the purported advantages of shifting out of regulation may be illusory. ${ }^{50}$

This dictum may also be a useful guide to analysis of possible antitrust interventions in markets not subject to regulation. Assume that a particular market does not perform well. Ideally, one ought to understand the dynamics of that particular market, and the purposes and effects in that particular market of discernible structural elements and conduct patterns. ${ }^{51}$ Indeed, it may be necessary to take account of motivations, and customary patterns, which are not explicable in terms of profit maximizing or anything else within the ken of conventional economic theory. ${ }^{52}$ Next one ought to consider possible ways in which the

${ }^{50}$ Williamson, Franchise Bidding for Natural Monopolies-In General and With Respect to CATV, 7 BELL J. ECON. 73 (1976).

${ }^{51}$ See generally L. Sullivan, Antrtrust $\$ 119$ (1977).

52 As one possible example, there is some empirical support for the insight of Judge Wyzanski, United States v. Minnesota Mining and Mfg. Co., 92 F. Supp. 947, 961-62 (D. Mass, 1950), that firms cooperating with each other in one context will be less likely to compete with each other in other contexts. See Mead, The Competitive Significance of Joint Ventures, 12 ANTITRUst BuLl. 819 (1967). Whether or not a general case can be made about the matter, it may well be that in some particular instances joint 
observed structure or conduct might be altered by a court decree. Only then is one in a position to evaluate whether the structure or conduct that a decree might mandate is likely to yield performance socially preferable to that which the market currently displays. Only if an affirmative answer is warranted does the potential intervention promise social advantage.

The Harvard approach differs from the Chicago approach in another important respect. At least the lawyers among the Harvard analysts struggle to deal in reasoned ways with constraints on the range of responses that are feasible, given that antitrust is not a program of economic planning but a system of rights and remedies enforced primarily through litigation in the courts. ${ }^{53}$ This effort to modify economic insights to facilitate their use by the courts is commendable. But it entails grave difficulties, as the recent debate concerning predatory pricing between Areeda and Turner, on the one hand, and Scherer, on the other, serves to reveal. ${ }^{54}$

The goal of the Areeda-Turner study was to develop economically sophisticated, yet judicially administrable legal rules for determining when price cutting by a firm with market power should be characterized as predatory. The authors take as the goal of competition an allocation of resources that is efficient in the short run and seek to specify simple objective functions to identify pricing strategies that distort efficiency. Suppose that a firm with market power charges a price below its short run profit maximizing price in order to discourage entry. At what point is the reduction to be characterized as predatory? Areeda and Turner conclude that a price reduction by the firm with market power ought to be characterized as predatory only if the challenged price falls below the firm's marginal cost or its average total cost, whichever is lower. ${ }^{55}$ The authors theorize that any

relations in one area may lead to dampened competitive striving in others. See Pfeffer and Nowark, Patterns of Joint Activity: Implications for Antitrust Policy, 21 ANTITrust BulL. 315 (1976).

${ }^{33}$ See, e.g., Areeda \& Turner, Predatory Pricing and Related Practices Under Section 2 of the Sherman Act, 88 HARv. L. Rev. 697 (1975).

${ }^{54}$ See Scherer, Predatory Pricing and the Sherman Act: A Comment, 89 Harv. L. Rev. 869, (1976); Areeda \& Turner, Scherer on Predatory Pricing: A Reply, 89 Harv. L. Rev. 891 (1976); Scherer, Some Last Words on Predatory Pricing, 89 HARv. L. Rev. 90I (1976), in which F.M. Scherer debates with Areeda and Turner the soundness of the thesis Areeda and Turner put forward in Areeda \& Turner, supra note 53.

${ }^{55}$ They also propose variable cost as a surrogate for marginal costs, because of the difficulty of determining marginal cost empirically. Areeda \& Turner, supra note 53, at 897. 
entry-deterring price reduction that did not fall below this baseline would not have any adverse resource allocation consequences. ${ }^{56}$

In rebuttal, Scherer first asserts that, in the output range where marginal cost exceeds average cost, short term anticompetitive consequences can occur if a firm with market power is allowed to price below marginal cost, but above average cost. ${ }^{57}$ Such a price would survive the Areeda-Turner test of predation, but Scherer reasons that if a new entrant could produce at minimum cost only by entry at significant scale, an actual or threatened preemptive expansion into the output range reducing price to a level between marginal and average cost would be an effective deterrent to entry.

Scherer's second criticism directly addresses the AreedaTurner goals of administrability and sophistication. He establishes theoretically that a price-equals-marginal-cost rule might maximize social welfare in the short run, but could have adverse long run effects on resource allocation. ${ }^{58}$ Scherer's theoretical dictum is that if as a result of a price reduction today future prices will be a higher percentage of costs than they would have been but for today's price reduction, then any judgment whether the price reduction is helpful or harmful to resource allocation must take into account the future efficiency losses as well as the current gains or losses. Scherer then hypothesizes circumstances in which price reductions not violating the Areeda-Turner rule would, by discouraging entry and facilitating higher prices in the future, adversely affect long run resource allocations. He proposes, in lieu of the Areeda-Turner test, a rule that characterizes as predatory only price reductions that, after analysis, can be shown to threaten resource allocation in the long run. This test would require consideration of a number of complex variables including the relative cost positions of the firm with market

${ }^{56}$ Given the pervasive "second best" problem, there is serious question whether an optimum allocation of resources, in the welfare economics sense, is a plausible goal for economic policy. See L. Sullivan, AnTrTRust, § 1(b) (1977). It is, however, a reasonable policy goal that prices in any industry be closely related to cost. While both Areeda and Turner and Scherer seem to have optimum allocation in the first sense in mind, it appears that their analyses neither gain nor lose force if one treats their concept of optimum resource allocation as though they had in view the more limited and seemingly more attainable goal of a close relation in any given industry between prices and costs.

${ }^{57}$ Scherer, supra note 54, at 869-75, 882-83.

${ }^{58}$ Id. 883-90. 
power and the potential entrants, scale economy relationships, whether the firm with power expands output as price is reduced, and, if so, whether the new output is maintained or withdrawn when the entry threat is overcome, and the like. The Scherer test would also require that a socially valid discount rate be adopted and used when summing future welfare losses with present gains or losses.

The Scherer analysis is theoretically convincing. Yet its economic sophistication betrays its lack of judicial administrability. As Areeda and Turner rejoin, the long run possibilities that Scherer urges the court to analyze are intrinsically speculative and indeterminate. Courts would have difficulty in dealing with them.

How is antitrust to respond when proponents of the two most comprehensive economic analyses available offer solutions at once so thoughtful and so unsatisfying? It may be that courts can avoid the dilemma only by looking beyond economic theory for ways of dealing with predatory conduct. If we are going to rely on judges and jurors to discover predatory practices perhaps their inquiry cannot be limited to price-cost relationships or focused exclusively on efficiency as a value. The traditional legal rule focuses on human animus. It speaks in terms of intent and identifies the predatory firm as one trying to inhibit others in ways independent of the predator's own ability to perform effectively in the market. Predation as conventionally viewed may involve grossly tortious conduct, like warehouse burning. A price reduction or expenditure is predatory where it has analogous qualities, when it is designed to impose losses on other firms in order to exclude them. ${ }^{59}$ The traditional rule, like the theoretical analyses here reviewed, takes competition as the central value. But instead of seeking objective indicia of competitive injury solely in the price-cost relationship it gives credit to the common insight that a purpose to avoid competition by disposing of competitors is likely to lead to competitive injury. The

59 Factors said to be indicative of "predatory intent" are analyzed in Utah Pie Co. v. Continental Baking Co., 386 U.S. 685 (1967); Moore v. Mead's Fine Bread Co., 348 U.S. 115 (1955); Balian's Ice Cream Co. v. Arden Farms Co., 231 F.2d 356 (9th Cir. 1955), cert. denied, 350 U.S. 991 (1956); National. Dairy Prods. Corp. v. FTC, 412 F.2d 605 (7th Cir. 1969); F.\&A. Ice Cream Co. v. Arden Farms Co., 98 F. Supp. 180, 189-90 (S.D. Cal. 1951). Cases are collected in Cooper, Attempts and Monopolization: A Mildly Expansionary Answer to the Prophylattic Riddle of Section Tiwo, 72 Mrch. L. REv. 373 (1974) and in Van Kalinowski, Business Organizations, Antitrust Laws and Trade Regulation, §§ 29.02, 37.04 (1976). 
traditional rule thus draws upon tort concepts and methodologies. It presupposes that there are norms of acceptable conduct in a competitive market as elsewhere, and that purpose is a useful guide in measuring conduct against those norms.

If this traditional rule governing predation is accepted, there are obvious factors to be examined in addition to price-cost relationships. A firm seeking to expel or exclude rivals by selling at unremunerative prices will leave traces; it will have gathered market information, considered it, and decided upon a course of conduct to attain its socially disapproved end. ${ }^{60}$ Pretrial discovery procedures are quite efficient in uncovering such traces and they are more easily proven than the pricing strategies condemned by either Scherer or Areeda-Turner. To contend that the conventional formulation of predatory conduct, which looks, in a sense, for evil, ought to be amended to one that looks solely to an effect validated by economic studies is to assume too much about the precision of applied economics and to assume too little-not just about the constraints on a trier of fact-but about the value of more humanistic modes of inquiry.

Rigorous analysis, like the Areeda-Turner and Scherer studies, obviously should be encouraged, and no doubt both will have practical use as well as theoretical interest. But the time has not yet come to abandon the conventional approach; Scherer seems right about the limitations of the Areeda-Turner rule and Areeda and Turner seem right about the complexities of the Scherer approach. Moreover, the conventional rule may successfully ferret out instances where harm is done to resource allocation in the short run that would escape detection under the Areeda-Turner rule. Areeda and Turner envisage two basic situations. ${ }^{61}$ In the first, the plant of the firm with market power is well adapted to producing at the output that maximizes its return. Where there were significant scale efficiencies, new entry would be warranted only if the entrant were able to obtain a substantial portion of the presently unmet "residual demand"that is, demand from buyers who will not pay as much as the profit-maximizing price now charged by the firm with power but who would pay more than cost plus a fair return to a firm producing at efficient scale. In the second situation, the firm with power is operating with substantial excess capacity. Scherer in-

611 L. Sullivan, Antitrust \$ 43 (1977).

61 Areeda \& Turner, supra note 53. 
fers, for cogent reasons, that preemptive expansion by the firm with power is more likely to occur in the first situation than the second. ${ }^{62}$ If it does occur in the first situation, the firm with power may be able to deter entry by reducing price to a level below marginal but not below average cost, a cut which, as Scherer shows, threatens short run resource allocations without violating the Areeda-Turner price-cost rule.

By contrast, a judge or jury operating under the conventional rule, with its focus upon intent, might well characterize such a price reduction as predatory. Such a trier of fact might have before it data similar to that on which the Areeda-Turner analysis is based; it might also have before it an analysis of that data showing the likely adverse long run effects of the firm's policy, an analysis comparable to the one done by Scherer in his criticism of the Areeda-Turner rule. Unconstrained by the Areeda-Turner rule it might infer from the data and the analysis that the price reduction was predatory. But even if such sophisticated material were not available, the trier of fact might well be provided with evidence of the perceptions held by the management of the price-making firm about its market situation, and evidence about the objectives management was trying to achieve by its pricing policy. These data, too, might lead to a conclusion of predatory intent. Thus, the conventional approach is likely to invalidate many of the price reductions which would escape the Areeda-Turner rule, even though, as Scherer shows, they are harmful to short run resource allocation. ${ }^{63}$

62 Scherer, supra note 54 , at 883 .

63 Two subsidiary points should be made. First, the conventional approach, being capable of finding predation where the Areeda-Turner test does not, is capable not only of characterizing as unlawful conduct that the Areeda-Turner test would treat as lawful, and which, if it were understood fully, would be seen to threaten long run injury to resource allocations, but is also capable of characterizing as unlawful conduct that the Areeda-Turner test would treat as lawful, and which, if it were understood fully, would be seen not to threaten long run injury to resource allocations. I see no theoretical or empirical basis for concluding that it will do the first more often than the second, or the second more often than the first. I do suggest that one ought not to screen out intuition and judgment in circumstances in which available instruments for measurement are demonstrably too blunt to be definitive.

Second, I do not argue that the conventional rule is as acute as is the Scherer approach in identifying price reductions that threaten long run resource misallocations. The Scherer approach is rejected as a comprehensive norm not because it is insensitive, but because it is unadministrable. In any event, the conventional rule would not foreclose an evidentiary presentation predicated on one of the Scherer models in any case in which credible evidence respecting the nature of relevant functions and of firm perceptions about them was available. Moreover, the conventional formulation seems less likely to yield results that may distort long run allocations than does the Areeda-Turner 
The best course, then, is to leave the avenues of inquiry as open as may be. Objective data, such as that stressed by Areeda and Turner, and even data responsive to the more complex analysis of Scherer, could then be used either to attack or defend, but so also could any other evidence indicative of predatory intent. A major focus would remain on intrafirm perceptions about the firm's competitive situation and the objectives of its pricing policy. ${ }^{64}$

In sum, economic theory is most useful to antitrust when those who are using it come most fully to terms with the richness and variety of the antitrust enterprise as a system of law. One must first allow that antitrust aims at values other than economic efficiency, that antitrust has other value sources. One must also allow that courtrooms are not laboratories for empirical investigation of issues framed by economists, but institutions for dispute resolution that have strengths and weaknesses explicable only in terms of the legal tradition. Once these concessions are made, it becomes possible to draw powerful analytical material from economics into the service of antitrust. But these materials must be transformed in the process, and seldom will they serve alone.

\section{The Uses of More Humanistic Disciplines in Antitrust}

If economics does not fully illuminate antitrust issues where else can one turn? In this section I attempt merely to suggest probable sources of insight and to share my thoughts about some of them.

If, as suggested above, the contemporary importance of antitrust lies primarily in its relation to the social and political dynamic through which power is allocated, sociology may contribute to an understanding of relevant relationships. The antinomies of conflict and consensus, stability and change, bureaucracy and democracy have been among the classic con-

rule. Lacking usable measures that are demonstrably more sensitive, it is plausible to conclude that we are more likely to protect against long run injury to competition by identifying those who are trying to injure competition than by relying on objective functions that are not attuned to long run effects at all.

${ }^{64}$ This course may also enable courts to avoid another problem associated with the Areeda-Turner test: difficulty in determining when profits exceed normal returns, a problem much stressed by some of the Chicago theorists. E.g., Brozen, Significance of Profit Data for Antitrust, in Public Policy Toward Mergers 110 (1968); Peltzman, Profit Data and Public Policy, in Public Policy Toward Mergers 128 (1968). In short, the conventional rule, which focuses on motive, may be more easily and sure handedly administered than the seemingly more objective price-cost rule. 
cerns of sociology.$^{65}$ Contemporary sociological research deals with many issues relevant to antitrust. Organization theory, ${ }^{66}$ the social aspects of economic development, ${ }^{67}$ social differentiation within business organizations, and the ways in which differentiation relates to organization size and related variables, ${ }^{68}$ the politics of bureaucracy, ${ }^{69}$ and theory about the way norms and values are legitimized and transformed ${ }^{70}$ all have potential significance.

A limited sociological literature addresses questions relating to corporate structure in ways that suggest the possibility that sociology may, in time, be able to make direct contributions to antitrust, much as does economics today. This literature focuses upon relationships between organizations and their environments and seeks to analyze the ways in which organizations modify and are modified by their environments. ${ }^{71}$ One branch of

${ }^{65}$ The value questions with which antitrust must deal have had the attention of sociologists for as long or longer than they have had the attention of economists. Alexis de Tocqueville addressed questions about the forces causing a centralization of power. A. De Tocqueville, Democracy in America 9-11 (Paris 1835) (Vintage Books ed. 1954). Max Weber's more theoretical treatment of bureaucracy has continued to influence modern sociological thought. See T. Parsons, The Structure of Social Action 503-13 (1937).

${ }^{66}$ E.g., C. Argris, Organization of a Bank (1954); P. Blau, The Dynamics of Bureaucracy (1955); A. Etzioni, A Comparative Analysis of Complex OrganizaTIONS (1961).

${ }^{67}$ Sociological literature dealing with economic development abandons the hedonistic assumption of many economists that "utility" is necessarily maximized by increases in consumption of economic goods, and seeks to identify with greater precision the way values and institutions are modified conjunctively with economic developmental processes. Most of the literature deals with underdeveloped societies, but the methodologies and theoretical concepts no doubt have wider application. For an excellent survey, see Moore, Social Aspects of Economic Development, in HANDBOoK of Sociology 882 (R. Faris, ed. 1964). N. Smelser, Social Change in the Industrial. Revolution (1959) is a brilliant study of effects of industrial change that utilizes both the methods of sociology and those of history. See also N. SMelser, The Sociology of ECONOMIC LIFE (1963).

${ }^{68}$ Here, again, there is a considerable literature, but most of it does not address issues of direct concern to antitrust. Yet, one comes away from the sociological material with the recognition that the quality of life varies in significant ways with significant differences in the scale, structure and characteristics of important institutions, like the economic ones, within which people function. S. Lipset \& R. Bendix, Social Mobility in INDUSTRIal Society (1959) is a basic contribution to the literature.

${ }^{69}$ Bureaucracy theory begins with M. Weber, The Theory of Economic and Social Organization (1947). The literature is vast and uneven. See Greer \& Orleans, Political Sociology, in HANDBOOK OF Socrology 808 (R. Faris, ed. 1964) for a survey.

${ }^{70}$ See, e.g., P. Nonet, Administrative Justice: Advocacy and Change in a Government Agency (1969). See also Nonet, For Jurisprudential Sociology, 10 L. \& Soc. REv. 525 (1976) (surveying the research tasks for sociology in dealing with law).

${ }^{71}$ For a survey of the recent literature see Aldrich \& Pfeffer, Environments of Organization, 2 AM. REv. Soc. 79 (1976). 
theory develops its models not by analogy to mechanics, as do economists, but by analogy to the biological sciences. Its basic theoretical concept is that in the long run organizations are differentially selected for survival in accordance with the fit between organizational structure and environmental characteristics. $^{72}$ Another branch of theory develops what are called "resource dependent" models. ${ }^{73}$ These theories, while owing something to the evolutionary analogy, insist that the need to survive need not constrain organizations severely because organizations can alter both themselves and their environments. Resource dependent theorists assert that the crucial questions that need to be illuminated concern the way organizations make choices about internal structure and conduct from among the array of all environmentally possible choices. ${ }^{74}$ As the phrase "resource dependent" implies, theorists in this group insist that organizations cannot generate internally all the resources needed to survive and that the ultimate goal that explains both changes in organizational structure and changes in the environment initiated by the organization is the need to attract resources from the external environment.

None of this theory is as advanced or as precise or supported by so wide an academic consensus as is much of microeconomic theory. Very little of it is ready to be drawn directly to bear on antitrust. ${ }^{75}$ However, the movement from the mechanical models of the economists to the more complex biological models of the sociologists is not lacking in appeal. It comprehends both intrafirm and interfirm phenomena; sociologists see a vital business organization capable within limits of transforming itself and its environment by interacting with other organizations. Such organizations are at once goaded and constrained by the expectations and demands of various constituencies. Internal control and decisionmaking itself involves a complex and dynamic interaction. Every firm is a microcosm to be described, analyzed and explained. The life process of the organization is not a quest for a single optimal solution, but a series of choices or compromises among alternative possible strategies,

\footnotetext{
${ }^{72}$ See, e.g., R. Hall, Organizations: Structure and Process 39-78 (1972).

${ }^{73}$ See Aldrich \& Pfeffer, supra note 71 , at 83.

is See J.D. Thompson, Organizations in Acrion (1967); White, Resources as Determinants of Organizational Behavior, AD. Scr. Q. 366 (1974).

${ }^{75}$ But of. Pfeffer \& Nowak, Patterns of Joint Venture Activity: Implications for Antitrust Policy, 21 ANTitrust Bull. 315 (1976).
} 
many having plausible appeal and several, perhaps, being backed by their own internal champions. This view, untidy and frustrating as it is, seems more realistic than the simpler and more orderly world of the economists.

In family law and criminal law sociologists have addressed explicitly some of the questions of interest to lawyers. In antitrust only economists have done so. What would develop if sociologists sought to explain pricing, product and other corporate decisions by reference to the dynamics of the social system of which corporate activities are a part? Well directed effort might yield knowledge about the attitudes, myths and ideologies that move those living their lives in corporate settings, knowledge sufficiently fine-grained so that differences could be perceived between the characteristics of decisionmaking in organizations of different sizes, for example. Do legal distinctions correspond with organic variations perceived by sociologists? How wide is the range of problems faced by corporate decisionmakers for which prevailing systems of belief provide clear answers? What happens when exogenous change confronts the corporate decisionmaker with realities that cannot be assimilated without stress? Social theory of any kind must simplify, but sociology may do so at a finer level than does economics. If conduct abnormal in the market is to be an indicium of predation, for example, ${ }^{76}$ surely the sociologist is better prepared than the economist to discern the norm and the aberration. We may yet attain better theory and empirical material about the welfare significance of changes in corporate structure than economics can avail.

The related discipline of political science is also of potential interest, particularly those aspects of it most closely akin to economics, which current practitioners sometimes call policy planning. ${ }^{77}$ The techniques of the policy planner in the antitrust area might enable us to isolate all of the social and political goals of competition, to identify the extent to which each of these is involved in specific situations where a policy choice must be made, and to identify by analysis the trade-offs that would be involved in alternative policy choices. This kind of analysis tends to be eclectic. Yet, there is a developing tradition with its own

${ }^{76}$ See text accompanying notes 59-60.

${ }^{77}$ For a discussion and criticism of much of the relevant literature, see Mueller, Public Choice: A Survey, 14 J. Econ. Literature 395 (1976). 
canons of excellence. Policy issues should be identified with specificity. Relevant value systems should be surveyed and policy criteria chosen, and the basis for these value choices should be explained. A range of possible alternative policies should then be selected for analysis, with the rationale for each being identified. After the preliminary steps are completed, the foreseeable effects of adopting and implementing each of the alternative policies should be analyzed. The analysis should be rigorous, yet more pragmatic than theoretical, and the analysis should be solidly based on available empirical data.

Consider, as an example, the question whether vertical resale restraints should be forbidden. An economic approach seeks to determine whether allocative efficiency would be helped or hurt by the intervention. ${ }^{78} \mathrm{~A}$ policy planning approach would ask, in addition, who cares? (More precisely it would try to determine who, if reasonably well informed and self regarding, ought to care, and why?) Such an inquiry would lead to an evaluation of present industrial practice and likely changes, assuming various possible public interventions that would consider not merely efficiency effects, but other identifiable social and economic effects. If resale restraints may be lawfully imposed by a manufacturer, dealers and consumers live in a somewhat different world than if such restraints are unlawful. When such restraints are imposed, there will presumably be both costs and benefits for dealers and consumers. For example, both of these groups will have fewer decisions to make. This reduction in their respective ranges of freedom, opportunity, and responsibility will for each group reduce both occasions for accomplishment and satisfaction and occasions for failure and frustration. A comprehensive analysis would explore and seek to evaluate all of these aspects of the system. Nor would it ignore the nonefficiency consequences on decisionmakers within the manufacturer's organization. Increasing the range of choice open to dealers and consumers reduces the range of choice open to executives of manufacturers. Finally, a policy planning analysis would try to analyze the political feasibility and the attendant costs and benefits associated with the legal intervention under consideration.

${ }^{78}$ Compare Comanor, Vertical Territorial and Customer Restrictions: White Motor and Its Aftermath, 81 HARv. L. REv. 1419 (1968), with Bork, The Rule of Reason and Per Se Concept: Price Fixing and Market Division, 75 Yale L.J. 375 (1966). See text accompanying note 38 supra. 
Conventional economics, useful as it is, gains some of its power and much of its rigor, then, by excluding relevant concerns that are difficult to quantify or to fit into mechanical models. Other social sciences may eventually prove useful to policy makers who ought to try to cope with some of the factors that conventional economics ignores. Yet even as the subject matter of the social theorists may inform antitrust with considerations beyond the ken of the economist, the mode of thought of any social scientist may impose other constraints. Most social science presupposes a dynamic system of interactions making it possible to trace the effects of changes in any one element in the system upon its other elements. All such thinking inevitably generalizes and simplifies as it systematizes. Are there yet other styles of inquiry and analysis from which antitrust might derive insights that have a keener eye for what is unique and particular in given institutions than the social sciences as a category provide?

That question points to the humanities; one thinks, of course, of history. It is a truism that history can enrich understanding of antitrust, but a truism much neglected. An historical outlook alters the perspective and affects what is to be seen. History itself reveals the variety of forces that fashioned the antitrust enactments, ${ }^{79}$ and the consequent multiplicity of goals the law may pursue. Yet a historical mode of perception further leads one to recognize that the social functions of antitrust are not fixed or settled, even at any single point in time, but are an item in ongoing policy debate. ${ }^{80}$ Indeed, at any given time various groups will find in antitrust quite different values and potentials. Today, a conservative might see antitrust as a means for assuring free markets wherever possible, as a rallying point, perhaps, for the deregulation movement. ${ }^{81}$ A liberal, depending on his particular persuasion, might see antitrust either as inhibiting movement toward effective social control of the economy by bolstering the market system, ${ }^{82}$ or as adding stability to the social and economic system, and thus to the political sys-

${ }^{79}$ See text accompanying notes 25-28 supra.

so It bears note that the ideas embodied in economic theory have also changed over time, and no doubt will continue to do so. Compare, e.g., Clark, supra note 25, with F. Scherer, Industrial Market Structure and Economic Performance (1970), each of which represents an orthodoxy for its period. See generally J. SCHUMPETER, History of Economic ANalogies (1954).

${ }^{81}$ See L. Sullivan, ANtitrust $\S 239$ (c) (1977).

82 See, e.g., K. Galbraith, The New Industrial State 184-88 (1967) (antitrust attacks the form rather than the substance of concentration by failing to police oligopoly). 
tem, by providing media for the expression of complaints about economic privilege and power. ${ }^{83}$ From a radical perspective antitrust might today be seen as an ameliorative charade. ${ }^{84}$ An historical perspective widens the student's view, allowing him to observe all aspects and evaluate their relevance. These general contributions of history, while perhaps the most important it has to make, are not likely to provide guides for the development of specific antitrust rules. History can, however, help those fashioning rules from falling into one or another kind of provincialism.

Moreover, the ways history can contribute may go beyond the general insights it offers. An historian explains past events, and the field of historical study includes economic, business and industrial events. The traditional narrative historian examining such events focuses on describing developments and explaining them. Any explanation of human events is in some sense a theory about how human beings act, but the traditional economic historian neither develops nor draws upon general theory about economic relationships. His purpose is no broader than to explain the particular sequence of economic events that he has described. ${ }^{85}$

Today, there is also a new style of historical inquiry into economic events, drawing more explicitly on theory, and fitting better with the social sciences than it does with the humanities. I refer to the work of the cliometricians. ${ }^{86}$ By finding ways to mine data from the past they are opening opportunities for industrial organization theorists, as for other economists, to refine theory through explorations of the factual resources of the past. In some instances, it may be possible to "test" theory, even for history to provide experiments in the form of situations duplicating theoretical models in which outcomes are already recorded in ways that can be compared with those the theory would predict. ${ }^{87}$

${ }^{83}$ See Blake \& Jones, supra note 36 , at $383-84$.

${ }^{84}$ Id. 377-78 \& n.3.

${ }^{85}$ See Habakkuk, Economic History and Economic Theory, 100 DaEdalus 305 (1971).

${ }^{86}$ Id. See also McCloskey, Does the Past Have Useful Economics?, 14 J. Econ. LITERATURE 434 (1976).

${ }^{87}$ A growing body of literature identifies historical questions amenable to quantitative investigation and the use of computers, and uses economic theory and economic models as bases for explaining past events. Prominent examples include R. FOGEL, Railroads and American Economic Growth (1964); R. Fogel \& S. Engerman, Time on the Cross (1974); P. Temin, Iron \& Steel in Nineteenth Century America (1964). While most model building historians seem to have relied on economics for theoretical equipment, there is, of course, no reason why theory drawn from other social sciences cannot be drawn upon to illuminate the past. 
Although the conjunction between history and economic theory explored by cliometricians shows potential for the finer critical development and use of economic theory, it does little to expand horizons beyond those of economic theory, to bring into the dynamic the kinds of affective material traditionally ignored by conventional economic theory. Indeed, cliometric methods, while perhaps enhancing the potential for rigor in historical inquiry, do so at a cost; much of the Muse's subtlety and perceptivity is inevitably left behind, and with these, her penchant for explaining events in humanly satisfying ways even when the explanation cannot be validated by a set of calculations. ${ }^{88}$ Students of antitrust, then, may turn to cliometrics with expectations much like those they now bring to economics; but they can also turn to current practitioners of a more conventional economic history with a very different kind of hope. There is, indeed, some very interesting non-cliometric economic and business history currently being done-studies that focus on particular industries, or on particular regions. Such studies explore processes of economic development and transformation by seeking to identify and understand the myriad interactions of economic, social, political, and fortuitous forces in the subject industry or region. ${ }^{89}$

In discussing the use of empirical and theoretical material from other disciplines, it is well to be mindful that the legal scholar, lawyer or judge may have special relationships to these materials that are functions of the needs of law and adjudication. History serves well as an example. One working in law may go to the past, much as he would go to the law library or to the empirical world immediately at hand. He brings with him a problem about the contours of a rule or policy arguably applicable to a particular case. He usually brings also a sense for the pos-

${ }^{88}$ To the extent cliometric literature limits its range of inquiry to material the relevance of which is validated by economic theory and, even more narrowly, to data amenable to quantification and computer analysis, it may miss much that is relevant and significant in explaining the past. It may signify something about both the potential and the limits of cliometric techniques to observe that some of the best work in this area is being done by scholars who profess to be economists, see, e.g., A. Fishlow, American Railroads and the Transformation of the Antebellum South (1965), and that the most severely criticized work comes from the hands of scholars who identify themselves as historians. See P. David, H. Gutman, R. Sutch \& P. Termin, Reckoning with Slavery; A Critical. Study in the Quantitative History of American Slavery (1976), which also identifies other deficiencies in the cliometric approach

${ }^{89} \mathrm{~W}$. Isard, E. Schooler and T. Vietorisz, Industrial Complex ANalysis and Regional Development: A Case Study of Refinery-Petrochemical-Synthetic-Fibre Complexes and Puerto Rico (1959). 
sible solutions. He already has views about what the rule or policy ought to be, and he is, in a manner of speaking, seeking validation in the past. He thus makes a first iteration of the past that may have more to do with his conception of the case at hand, and how it might be decided, than with what he already knows about the historical evidence. He then engages in a dialectic, as it were, between the historical sources and his tentative conception of law or policy. The goal of the exercise is to place the historical evidence in an ordered relationship with a satisfactory restatement of the rule or policy. The process may modify or even transform the investigator's view of the governing rule, but it would be a mistake to suppose that the past as he reconstructs it is independent of the predispositions implicit in the problems on which he is working. ${ }^{90}$

Among the humanities, history does not stand alone as a possible source of antitrust insight. Philosophical or jurisprudential inquiry may also illuminate current issues, particularly those that have to do with the way alternative values are to be integrated into the law. One might address these questions in a rationalistic spirit. In choosing among alternative antitrust rules effects on goals like economic efficiency and such social amenities as wider ranges of opportunity or choice for individuals would be of interest, but the ultimate goal of analysis might be to identify not the rule most conducive to the maximization of these values, but the rule most conducive to such a maximization of them as is consistent with their just distribution..$^{91}$ I am not suggesting that trade-offs between greater efficiency and a less just distribution would be barred. From John Rawls' position I take it that it would be, ${ }^{\mathbf{9}}$ but others may find greater appeal in alternative ethical positions. ${ }^{93} \mathrm{I}$ am suggesting no more than an additional complication for the social calculus. It may not be enough to ask which rule yields the greatest efficiency or even which rule maximizes individual opportunity. It may be necessary, in addition, to ask who is benefited, and in what degree, and to consider the justice of that distribution.

90 It might be argued that the process here envisaged is not vastly different from that in which historians generally engage. See B. CROCE, History and Chronicle, in History: Its Theory and PRACTICE 11, (1921). For an engaging and perceptive history of the philosophy of history, see R. Collingwood, THE IDEA OF History (1946).

${ }^{91}$ See, e.g., Feinberg, Book Review, 81 Yale L.J. 1004 (1972) (J. Rawls, A Theory OF JUSTICE).

92 J. Rawls, A THeORY OF JUSTICE (1971).

${ }^{93}$ See Feinberg, supra note 91. 
None of this is intended to assert that there are storehouses bursting with grains of wisdom to which hungry antitrust theorists need only turn. Indeed, what seems most instructive about explorations of the policy planning and jurisprudential literature is that materials from these disciplines display the complexity that underlies policy questions such as those encountered in antitrust. If those disciplines fail to supply answers, they may at least call forth a healthy skepticism about more limited analyses such as those drawn from conventional economics.

\section{The Uses of Legal Scholarship in Antitrust}

Finally, scholarship can bring anew to antitrust the traditional modes and methods of legal analysis. Antitrust is, after all, a system of law. That was the congressional choice, and who is to say it was not a suitable one? Being law, largely judge-made law, antitrust partakes of the values eminent in the American common law tradition. Major problems to be faced in antitrust during the next decade or so must be solved primarily by drawing upon this tradition. The interplay of the federal mandate to compete and state law regulatory regimes comes immediately to mind. With its decision in Cantor 2. Detroit Edison Co.,${ }^{94}$ the Supreme Court, after a lengthy excursion, has returned to a root path. There remains the task of seeking accommodations between congressional expressions of a national consensus and cross currents of state legislative or regulatory policy. In that process values drawn from judicial experience with federalism will weigh heavily and, no doubt, will modify perceptions about the urgency of the various alternative substantive policies that may be involved in particular situations. Sorting out what is most salient from all that is relevant, identifying possible ways of resolving apparent conflicts by accommodating contending interests rather than sacrificing one to another, sensing the potency of a state or federal policy and the force and directions of its potential for growth, are all tasks uniquely suitable to the institutions of the law.

There are other needs that can only be met through the

${ }^{94} 96$ S. Ct. 3110 (1976). Cantor held that respondent utility's light bulb distribution plan, implemented pursuant to tariffs approved by the state regulatory agency, was not exempt from the ban of the Sherman Act because of such approval. The Court distinguished Parker t'. Brown, 317 U.S. 341 (1943), as immunizing from antitrust scrutiny only "official action taken by state officials," not "private action taken under color of state law." $96 \mathrm{~S}$. Ct. at 3117. 
conventional techniques of legal analysis and synthesis. One is to develop procedures allowing all with an interest to be represented. Antitrust deals with questions of broad social and economic policy. It is anomalous that these issues should be dealt with as a system of legal rights, obligations and remedies, enforced primarily through adjudication. Often, particularly in structural litigation, persons who may be significantly affected are not before the court. Resulting procedural and remedial issues deserve scholarly attention that can probably come most usefully from lawyers.

Antitrust makes yet another, more general, perhaps more basic demand on scholarship because antitrust is a system of law, a demand to which legal scholars are particularly equipped to respond. Harvard scholarship, as I suggested in the first section, has been sensitive to the need for antitrust rules of general application. But the overall problem is larger than this. Antitrust ought to be a system of interrelated legal rules reflecting values and derived from principles which are legitimate within the context of the American tradition of judge-made law. In dealing with precedent the processes in which first semester law students are rigorously drilled ought to be at the forefront. Processes of analysis and synthesis, the conventional business of deciding what prior cases hold or imply ought to be carried out in demonstrably reasonable ways and expressed with clarity. ${ }^{95}$ Wechslerian "neutral principles" ought to be discernibly at work. ${ }^{96}$ The sources of values and principles that inform decision ought to be expressed as clearly as possible and their legitimacy ought to be defended by reference to legislative or constitutional norms or to moral or institutional norms assimilated over time as a part of the conventional process of judicial lawmaking. ${ }^{97}$ No more in antitrust than elsewhere should courts act as though each case were sui generis, a single pebble on a sandy beach. The conventions that legitimize adjudication must apply and a manageable system of rules of general applicability must be developed.

Scholarship can contribute to this development in antitrust in ways no other institution can match. In the past, it has done so primarily by seeking to integrate law and micro-economic

\footnotetext{
${ }^{95}$ See, e.g., Levi, The Nature of Judicial Reasoning, 32 U. CHI. L. Rev. 395 (1965). (1959).

${ }^{96}$ Wechsler, Toward Neutral Principles of Constitutional Law, 73 HARv. L. REv. 1

${ }^{97}$ Compare H. HaRT, THE Concept of LAw (1961) with Dworkin, Hard Cases, 88 HaRv. L. Rev. 1057 (1975).
} 
theory. I am suggesting that it ought now to take up related tasks. There is a "higher criticism" of judge-made law that examines judicial craftsmanship, value sources, and the complexities, aptness, and legitimacy of institutional arrangements through which legislative, judicial, state, and federal power are accommodated to each other..$^{98}$ By and large this criticism has been reserved for constitutional adjudication, federal jurisdiction and conflicts of law. Intellectual and institutional issues fully as challenging are involved in antitrust and directly related fields. Indeed, there are basic tasks to be done. Existing case law must be brought into conceptual order. There is a need to identify and express the analogies and distinctions that render results credible by putting them into ordered relation to other results, thus giving them doctrinal forms and larger meanings. There is a need to relate such doctrinal statements to the historical development of the law in a fashion that gives emphasis to elements of constancy, transformation, and novelty. There is a need to specify the way these doctrinal concepts relate to generalizations of a wider scope or higher order, having an ethical or a policy content drawn from economics or elsewhere with a legitimate place in the development of the law. The scholarly agenda is a large one, and transcends, I think, the adaptation of conventional economic analysis, however important that task may continue to be.

${ }^{98}$ See Hyman, Constitutional Jurisprudence and the Teaching of Constitutional Latw, 28 Stan. L. Rev. 1271 (1976). 